\title{
Impact Assessment of FLD on Adoption Level of Farmers in Relation to Rabi QPM Production Technology
}

\author{
Veeresh Kumar ${ }^{1}$, M. N. Ansari² ${ }^{*}$, Ajay Kumar ${ }^{1}$ and Anil Kumar Sharma ${ }^{3}$ \\ ${ }^{1}$ All India Coordinated Research Project on Maize, ${ }^{2}$ Department of Extension Education \\ ${ }^{3}$ College of Horticulture \& Forestry, Piprakothi, Tirhut College of Agriculture, \\ Dholi, Muzaffarpur, Bihar \\ *Corresponding author
}

\section{A B S T R A C T}

Keywords

Adoption Level,

Farmers, QPM

Production

Technology

Article Info

Accepted:

10 March 2020

Available Online:

10 April 2020
The study was found that the majority of demonstrating farmers did have the high adoption towards Rabi QPM production technology as compared to the non-demonstrating farmers. The differences in adoption of both the categories of farmers were also found to be significant. The rational analysis showed that out of ten independent variables in case of total farmers, seven variables namely; education, annual family income, cropping intensity, fertilizer consumption behaviour, degree of contact with the extension agency, innovations proneness and attitude were found to be significant with the level of adoption towards maize production technology. The FLD had good impact in terms of adoption of Rabi quality protein maize production technology.

\section{Introduction}

Maize occupies an important place in the world agriculture. It is one of the most important food, feed and fodder crop .It can be utilised in various form at different stages of its growth and development. Recently, due to development of Quality Protein Maize, It is widely used for bread purposes and also diversified as more than thousand industrial products. In India, it is most potential cereal crop after rice and wheat. Bihar is a leading state in growing Rabi Maize and farmers are harvesting about 8 tonnes per hectare with hybrids during Rabi and 6 tonnes per hectare in Kharif.

There is further scope of increasing production and productivity of this crop in the state. Realizing this fact, the Indian Institute of Maize Research is providing extension service to the nation through FLD. Keeping this in view; the study was conducted with the following objectives. 
To ascertain the differential impact of FLD on the adoption level of farmers.

To examine the relationship between selected socio-economic and personal variables with the level of adoption of Rabi QPM.

\section{Materials and Methods}

The study was conducted in Muzaffarpur, Samastipur, Vaishali, Madhubani, and Buxar districts of Bihar state. AICRP Maize of Tirhut College of Agriculture, Dholi centre conducted FLD in the above district in the year 2013. A total of 120 farmers constituted the respondents among which 60 were demonstrating and rest were non demonstrating farmers.

The data were collected by personal interview method by using pre-tested interview schedule developed for the study and number, percent, mean \& correlation were used to draw meaningful conclusions.

\section{Results and Discussion}

\section{Adoption towards the rabi QPM production technology}

Adoption behaviour is a complex process. It requires a favourable mental set and a successful physical act. It is a decision to make full use of new idea as the best course of action.

The adoption of Rabi QPM production technology was measured by adoption index. On the basis of adoption index the respondents were classified into three groups' viz., low medium and high. The distribution has been presented in Table 1 .

It was clear from the table that among demonstrating farmers, 86.67 percent respondents were having high level of response towards adoption and merely 13.33 percent were having medium level of adoption.

However, in case of non-demonstrating farmers, 33.33, 60.00 and 6.66 percent of respondents were having high, medium and low level of response, respectively, towards Rabi maize production technology.

None of the farmers was having negligence towards adoption of Rabi QPM production technology in demonstrating case.

Further to find out whether this difference was statistically significant or not, two sample $\mathrm{t}$-tests (paired t-test) was followed and the result was presented in Table 2.

The table revealed that $t$-value in respect of the difference in the adoption of demonstrating and non-demonstrating farmers towards Rabi QPM production technology was found to be 3.781 which was statistically significant.

This was indicative of the fact that there was response of the FLD programme and this programme had been effective in achieving its objective between demonstrating and nondemonstrating farmers. The present finding is supported by the findings of Gogoi et al., (2000).

\section{Relationship of selected socio-economic and personal variables with the level of adoption}

The correlation coefficients indicating the nature and degree of association between adoption with the independents variables in case of demonstrating, non-demonstrating and total farmers has been presented in Table 3 . 
Table.1 Frequency distribution of respondents by adoption of Rabi QPM production technology

\begin{tabular}{|c|c|c|c|c|c|c|}
\hline Category & \multicolumn{2}{|c|}{$\begin{array}{c}\text { Demonstrating } \\
\text { farmers }\end{array}$} & $\begin{array}{c}\text { Non-demonstrating } \\
\text { farmers }\end{array}$ & \multicolumn{2}{|c|}{ Total farmers } \\
\hline & $\mathrm{F}$ & $\%$ & $\mathrm{~F}$ & $\%$ & $\mathrm{~F}$ & $\%$ \\
\hline Low & 0 & 0 & 4 & 6.66 & 4 & $\mathbf{3 . 3 3}$ \\
\hline Medium & 8 & 13.33 & 36 & 60.00 & 44 & $\mathbf{3 6 . 6 7}$ \\
\hline High & $\mathbf{5 2}$ & $\mathbf{8 6 . 6 7}$ & $\mathbf{2 0}$ & $\mathbf{3 3 . 3 3}$ & $\mathbf{7 2}$ & $\mathbf{6 0 . 0 0}$ \\
\hline
\end{tabular}

Table.2 Difference in the adoption level towards Rabi QPM production technology of demonstrating and non-demonstrating farmers

\begin{tabular}{|c|c|c|c|c|}
\hline $\begin{array}{c}\text { Mean of } \\
\text { Demonstrating } \\
\text { farmers }\end{array}$ & $\begin{array}{c}\text { Mean of Non- } \\
\text { Demonstrating } \\
\text { farmers }\end{array}$ & $\begin{array}{c}\text { Difference of } \\
\text { means }\end{array}$ & $\begin{array}{c}\text { Pooled value of } \\
\text { standard } \\
\text { deviation }\end{array}$ & t-value \\
\hline 41.23 & 30.37 & 00.86 & 05.83 & $03.781^{*}$ \\
\hline
\end{tabular}

*Significant of 0.05 level of probability

Table.3 Correlation coefficient of independent variables with the level of adoption of farmers towards the Rabi QPM production technology

\begin{tabular}{|c|c|c|c|c|}
\hline \multirow[t]{2}{*}{ SI. } & \multirow[b]{2}{*}{ Independent variables } & \multicolumn{3}{|c|}{ r-value of } \\
\hline & & $\begin{array}{l}\text { Demonstrating } \\
\text { farmers }\end{array}$ & $\begin{array}{l}\text { Non- } \\
\text { demonstrating } \\
\text { farmers }\end{array}$ & Total farmers \\
\hline 01. & Age & $-0.4270 * *$ & $-0.4110 * *$ & $-0.4227 * *$ \\
\hline 02. & Education & $0.3873 * *$ & $0.3262 *$ & $0.3541 * *$ \\
\hline 03. & Annual family income & $0.3369 * *$ & 0.2343 & $0.2917 * *$ \\
\hline 04. & $\begin{array}{l}\text { Fertilizer consumption } \\
\text { behaviour }\end{array}$ & $0.2877 *$ & $0.3477 * *$ & $0.3235 * *$ \\
\hline 05. & Cropping intensity & $0.2738 *$ & $0.3253 *$ & $0.2887 * *$ \\
\hline 06. & Risk preference & -0.1456 & -0.1261 & -0.0915 \\
\hline 07. & $\begin{array}{l}\text { Degree of contact with the } \\
\text { extension agency }\end{array}$ & $0.2656^{*}$ & 0.1592 & $0.2263 *$ \\
\hline 08. & Innovation proneness & $0.3463 * *$ & 0.1523 & $0.2538 * *$ \\
\hline 09. & Economic motivation & 0.1609 & 0.0894 & 0.1308 \\
\hline 10. & Attitude & $0.2975 *$ & $0.2852 *$ & $0.2989 * *$ \\
\hline
\end{tabular}

*Significant at 0.05 level of probability.

**Significant at 0.01 level of probability.

It was amply clear from the table 3 that out of ten variables studied, four variable, viz; education, cropping intensity, fertilizer consumption behaviour and attitude towards Rabi QPM production technology had been significantly and positively, where as one 
variable age was significantly but negatively associated with the adoption in both the cases of demonstrating and non-demonstrating farmers. Significant positive correlations for annual family income and degree of contact with the extension agency were found in case of demonstrating farmers.

The variable innovation proneness showed significant with positive association with adoption in demonstrating farmers' situation. In case of total farmers, as many as seven variables, namely, education, annual family income, cropping intensity, fertilizer consumption behaviour, degree of contact with the extension agency, innovations proneness and attitude towards Rabi QPM production technology had been found to be significantly and positively correlated, where as the age was significantly with negatively associated, with the adoption process. Similar findings were also reported by Borah and Bhagowati (2000).

\section{References}

Borha, B.S. and Bhagowati, A.K. (2000). Adoption behaviour of rural farmers of Assam towards different aquaculture technology. Word Agril. Economic of Ext. Edu. XIX: 130-131.

Dhillon, G.S. and Kuldip, K (2007).Adoption of improved Mentha cultivation. India. J. Extn. Edu. XXXX (3\&4) : 40-43.

Gogoi, M., Phulkan, E. and Tralukdar, R.K. (2000). Impact of farmers training programme on adoption of rice production technology by farmers. Maha. J. Ext. Edu. XIX: 232-238.

Nirmal Chandra and Bisht, K.K. (2008). Adoption trends of improved Agricultural Technology in the villages of Uttaranchal, India. J. Extn. Edu. 44: (1\&2): 70-73.

\section{How to cite this article:}

Veeresh Kumar, M. N. Ansari, Ajay Kumar and Anil Kumar Sharma. 2020. Impact Assessment of FLD on Adoption Level of Farmers in Relation to Rabi QPM Production Technology. Int.J.Curr.Microbiol.App.Sci. 9(04): 841-844. doi: https://doi.org/10.20546/ijcmas.2020.904.101 